\title{
United States of America and Constitutional Guarantees
}

\author{
Ana Dhamo \\ PhD cand. TIrana European University, Albania
}

Doi:10.5901/mjss.2015.v6n3p242

\begin{abstract}
In different cases United States had limitations of human rights and civil liberties in the name of internal security and the problem of the relationship between freedom and security. This fact is present in the history of the United States from origins of Federation and is one of the arguments discussed by politicians and researchers. In 1787, during a discussion regarding the ratification of the new Constitution, Alexander Hamilton tipped off that the restriction of freedoms would always implication war and fear and stated that in some situations, the new Constitution will be ignored. In this way, the United States will have, according to Hamilton's tendence to destroy their civil and political rights. So, in order to be sure would run the risk to be less free. This prediction was verified in some circumstances and now is again discussion topic after September 11 and the adoption of the Patriot Act.
\end{abstract}

Keywords: constitutional guarantee, United States, habeas corpus, civil rights, Constitution, civil war. II World War, I World War.

\section{Introduction}

Throughout history, in different cases United States had limitations of human rights and civil liberties in the name of internal security and the problem of the relationship between freedom and security. This fact is present in the history of the United States from origins of Federation and is one of the arguments discussed by politicians and researchers. In 1787, during a discussion regarding the ratification of the new Constitution, Alexander Hamilton tipped off that the restriction of freedoms would always implication war and fear and stated that in some situations, the new Constitution will be ignored. In this way, the United States will have, according to Hamilton's tendence to destroy their civil and political rights. So, in order to be sure would run the risk to be less free. This prediction was verified in some circumstances and now is again discussion topic after September 11 and the adoption of the Patriot Act. I have made a step back and to turn our attention to the historical periods in which the war and its fear have resulted in reactions of this nature. Historical analysis shows how to respond to periods of crisis by limiting freedom, has always been a common idea of all American governments, the Republicans and the Democrats, even those governments that we were in appearance and careful to freedom and individual rights. Historically, the American people have always supported government elections in this regard, asking strangle measures that at the same time to guarantee more safety: it even by those who have always believed in the inviolability of their individual rights. Basic orientation, however, was that the provisions should turn to a narrow number of individuals, identified by race, origin or political ideas. Also these measures should be taken only during the emergency, should therefore be temporary. In times of need some constitutional protections can be abolished, and can also sacrificed the rights of some individuals, although American citizen. This fact is always considered legitimate in more safety of all other American citizens. An essential role played systematically the fear and insecurity of the country. In moments of crisis issue is not whether the fear is well founded or not abstractly; sometimes cannot be, and can often be exaggerated, but the majority of cases is probably motivated. It was after the attack of Pearl Harbor, was during the Cold War and is probably today after the 11 September 2001 attacks.

The question to ask ourselves is whether the regulatory actions taken to respond to this fear or not needed. First criterion for assessing the restrictive provisions of the civil rights seems to be their effectiveness, efficiency in terms of the ability to limit risks to the country and to increase national security. Only after it is completed secondary evaluation of the effects of these measures most think that may be considered negative due to the freedom of citizens. If, before a real danger for the country, a law is unable to protect national security, he positively evaluated whether its due temporarily restricted the exercise of civil rights. This does not mean that the Constitution does not apply in time of war, but means that at the time of application of a constitutional standard applicable in every area of law is helpful to be taken into consideration conditions of war to decide whether the government owns or no excuses necessary to limit constitutional rights. But not always in American history has been so. In many cases has been answered critical situations with 
inadequate measures and not proportional, other times of crisis and fears have been exploited by the American government for achieving political goals that had no relation to national security. The beginning of this paper with a brief historical analysis can be useful to evaluate the different measures taken in the past as a response to critical periods, to evaluate the specific effects and response of public opinion and media and finally to analyzing the important role that the Supreme Court had occasionally, overcoming governance policies or in resolving emergency situations.

It would be impossible to recall all the examples of restrictions of civil liberties in the history of the United States; possible, on the other hand, a short analysis of the most important legislative chains and analytically drop in three moments that seem to representatives. Alien and Sedition Act passed in 1798 (less than ten years from the adoption of the Constitution) represent the first laws through which Congress adopted strong measures freedom of speech against individuals suspected of anti-government position. Laws were torn down in 1802 when the Republican Party took power. Fifty years later, after the outbreak of civil war, President Lincoln and Congress allowed investigations, detentions and other actions against citizens suspected of anti-government actions. During the war Lincoln interrupted Habeas Corpus-in in different situations and established military court although contrary to the Supreme Court. They were arrested during the war a number of the involvement between 10,000 to 30,000 American citizens without due process of law and without any constitutional guarantees.

At the beginning of World War Congress began to take into account the possibility of adoption of a law which limit the freedom of expression during 1916 and adopted various legislative texts, but none of them ever reached a majority vote in both chambers. Only in the following year to June 15, 1917, was passed Espionage Act, in force even to this day, is further amended by the Sedition Act. These acts authorizing the use of force, to prevent the broadcasting of dangerous information for national security and allow the arrest of those explaining comments or opinions against the war. They banned the pronouncement of discussions and printing leaflets against the United States, the Government, the Constitution and Flag. These two laws brought in the period called the "Palmer Raids" or "Red Scare". At the beginning of 1920 as a result of the explosion of a bomb before the house the Attorney General A. Mitchell Palmer, verified a series of arrests at the expense of suspected terrorists, above all foreigners. There were nearly 2,000 individuals detained because of the Espionage Act: half of these were convicted, but none on charges of espionage. During the war, the Supreme Court said there ever about Espionage Act and Sedition Act; in the coming years in six different cases judged legitimate laws and confirmed the sentences handed as American citizens. Only in 1920 Congress withdrew laws and given freedom to those who were convicted of Espionage Act and Sedition Act. Even Court returned to the steps in her and canceled all decisions taken earlier during the First World War.

One of the most important positions in the history of the United States in connection with the termination of constitutional guarantees in emergencies, expressed by Abraham Lincoln in a letter written in 1863 in justification of its decision on the suspension of habeas corpus's and jailed indefinitely for his opponents during the civil war. Lincoln in this paper deals with the main issue, namely whether the limitations of these guarantees in time of war, may cause permanent damage to constitutional guarantees. Lincoln says that, in its application, the Constitution cannot be considered in the same way in all cases. It formulates amending the Constitution itself; well, the Government may use coercive measures during the state of emergency on the basis of the fact that these measures are not used, since they are illegal, peace time. Another point on which we must reflect is the question of what these elections bring about the efficacy of the law at the time of completion of emergency. Lincoln reiterated that the termination of civil liberties in times of emergency not compromise the constitutional in peace. Many were those who supported the fact that temporary interruptions nature tend to become more sustainable and their application areas tends to be expanded. According Lincoln projections contained in the Constitution of the United States are more valuable than those provided by the new European ones, which contain a long list of assumptions for setting rates emergency in time of war and civil war. In 1863 Lincoln defended the measures that were taken, among which is the suspension of habeas corpus statue, the fact that these measures, legitimate or not, are taken by observing what was the will of the people and public needs. There may be excluded from the executive to declare emergence, but after the declaration of emergency Parliament and the courts have the right and obligation to investigate the exercise of such emergency powers.

As mentioned above, Lincoln interrupted -it guarantee of habeas corpus in eight different situations. It extremes, which was applied to an entire state, stated that "all persons ....... guilty of any unfair action ... will be subject to court martial." Under this authority, the military agents arrested and detained at least 38,000 civilian without judicial proceedings or decision. State Secretary- William Steward commented before the British Minister in Washington: "We can pick a ring on my right and order the arrest of a citizen in Ohio. Can you pick a ring again and decide imprisonment of a citizen in New York, and no one on earth except the President cannot release them. Queen of the United Kingdom could say the same for its citizens? ". Here noticed a simple sarcasm US State Secretary with the British Minister.

At the beginning of the Civil War judge Roger Taney, ruled that the termination of habeas corpus by Lincoln -it -it 
represented an unconstitutional violation and abuse of that authority because under the Constitution, only Congress had the power. Lincoln simply ignored the ruling of Judge Taney, defending his action as necessary to save the US -we from destruction.

Most military arrests caused by the offense in opposition to military service, sabotage and agreements with the enemy. Few individuals were arrested for political rallies or demonstrations of ideas. An example of these arrests for controversial discussions, represented by Clement Vallandingham case, a former Congress MP -as Ohio who was an opponent of Lincoln -it extraordinary. Vallandingham was sentenced by a military court and subsequently by Lincoln after holding a discussion in Ohio in which described the Civil War by the White House.

In 1886, a year after the civil war, the Supreme Court ruled that Lincoln had exceeded its constitutional authority, supporting the fact that under the Constitution the President can not suspend the right of habeas corpus statue, nor in time of war, if juries civilian were open and functional.

Court noted: "The Constitution is a law for rulers and for the people, as in time of war as well as in times of peace, and protects all classes of the population, at any time and under any circumstance. Never been conceived by human intellect with a doctrine Such consequences it implies that any provision thereof may be terminated in the range of Riley with special needs to the government. Such a doctrine sends directly to anarchy and dispotic ".

These few lines explain that Lincoln us during the Civil War proved as if it were a dictator, while stopped for the first time in the history of United States constitutional guarantee of habeas corpus statue, an essential guarantee of the right anglossaction.

\section{Constitutional Guarantees during the First and Second World Wars}

The history of civil liberties during the First World War is too scary. As in any conflict, even during the Great War have assisted in repeated restrictions of civil liberties in the United States. When the United States entered the war in April 1917, had a strong opposition against the war as well as against military service.

Then President Wilson did not tolerate these objections. He stressed that the lack of loyalty "should be eliminated" and that she "did not constitute an argument over which is no room for discussion". Controversial subjects under Wilson had sacrificed their rights to civil liberties. Shortly after entering the war United States, Congress had approved Espionage Act in 1917. Although the direction of mass opposition is not general, prosecutors federal aggressive and federal judges, and transformed it into a general ban dubious expressions. The purpose of the administration in this regard became evident in November 1917, when Attorney General Charles Gregory, referring to the conflict opponents said: "God have mercy on them, in order that they do not expect from a nation of prejudice or by a vengeful government ". In fact, the government worked convincingly to create "a nation of prejudice". Given that there was no direct attacks against the United States, and no threats against their security, Wilson administration should produce a sense of need to invite Americans were part of the army, the contribution with their finances and make sacrifices that the war demanded. For this purpose Wilson created the Committee on Public Information, which produced a series of discussions, editorials and movies, more frequently invention, all directed to oppose Americans a feeling of hatred against the Germans and against all those persons whose justice to be suspected.

During World War Government condemned over 2,000 individuals because of their opposition to be part of the army or to participate in war. In this atmosphere of fear, judges took serious decisions (from 10 to 20 years in prison) for those who were considered guilty of treason. Few were they judges you courageously resisted this trend repressive, the majority followed the lead of the moment. The result was the suppression of any debate on this topic, morality and war developments.

But anyhow it was not enough. Only a year after Congress passed the Sedition ACT in 1918 which expressly forbade any expression of controversial and offensive against the United States. Neither truce did not close this phase. Attorney General A. Mitchell Palmer sent a series agents aiming their infiltration in some radical organizations. In a span of two months only government arrested over 5,000 thousand American citizen, by deporting the various proceedings with a thousand foreigners suspected of being part of radical groups.

History of the Supreme Court in this period is too excruciating to tell. In a series of decisions between 1919 and 1920 confirmed Court conviction of citizens who had resisted military service and war. Among these individuals might remember the case of a Russian Jewish immigrant, Mollie STEIMER, 20 years old, which was cast in Yiddish antiwar leaflets from the roof of a building in the East Side of New York - Regulation. Another case is that of Eugene Debs, who had received nearly a million votes in 1912 as the Socialist Party candidate for the presidency of the United States. Were decisions that have not left doubts about the position of the Supreme Court, while the nation was at war flak was not part of the constitutional protection. May affirm the decision of the Court -it was terrible. 
In December 1920, as the situation calmed somewhat, the Congress without any problem attracted Sedition Act in 1918. Between 1919 and 1923, the government released all those individuals who were arrested due to Sedition and Espionage Acts. Ten years later, President Franklin Delano Roosevelt decided an amnesty for all those individuals, by the return of their political rights and civil. In the next half century, the Supreme Court annulled all decisions made during the First World War, claiming that each of the individuals arrested or deported at that time because of their opposition, was convicted of statements that should be protected the First Amendment.

On December 7, 1941 Japan attacked Pearl Harbor base. Two months later, dated February 17, 1942 President Roosevelt signed an executive warrant 9066, which authorized the army to "find military area from which any person with American citizenship should be ruled it". Although the word "Japan" or "Japanese American" appear not ever in this order, was implicit reference the fact that the persons exclusively Japanese origin.

In this measure, 120,000 citizens of Japanese descent were forced to leave their homes in Washington, New York, California, Oregon and Arizona. Two-thirds of these individuals were American citizens and representing nearly $90 \%$ of all Japanese American. There were released charges against these citizens; they do not know the reason for which they were removed from their homes. They did not know where they were going and how long you will stay. Many families lost everything they had.

In order military police were transported in one of ten camps isolation occurred in isolated areas. Men, women and children were placed in overcrowded rooms. It was found surrounded by soldiers and plug wire and remain there for three long years.

One of the most obvious cases of deportation of Japanese nationals, was the Toyosaburo Korematsu. The court gave the following explanation:

"We do not ignore the suffering caused to a wide group of American citizens. But suffering are part of the war, and war is a set of suffering. Korematsu not left the west coast because of race, but military authorities have decided that the urgency of the situation create required all citizens of Japanese descent were deported from that area. We can confirm that these initiatives were justified ".

In 1980, Congress created the Commission for the isolation of civilians in time of war, to review the Japanese American internment. In 1983, we concluded the Commission unanimously that the factors that provoked isolation "had e racial trials, and bankruptcy of policy's Leadership", rather than military necessity.

Soon after a federal court to a lower grade, decided an extraordinary principle in the case Korematzu, proving that government agents were aware at that time in terms of departure, that there was no military necessity, and that we 1944 government agents had deliberately lied to the Supreme Court on this issue. We cancellation of conviction for Korematsu n 40 years ago as a result of a manifest injustice, Federal Judge Marilyn Hall Patel enfasis need of executive responsibility.

Korematzu shows a constant care whereby in time of war or military emergency should ensure institutions to protect constitutional guarantees.

This case demonstrates the care with which we wartime institutions executive, legislative and judiciary should be prepared to exercise their authority to protect the constitutional freedoms of individuals.

\section{Conclusions}

In the framework of a constitutional guarantee for individuals and States in general, the constitutional lawmaker United States of America should pay attention and utmost care case interruption that constitutional guarantees, namely in respect of freedom and happiness that expressed and proclaimed with such patriotism by the founders of the United States of America.

\section{References}

Adam, James A. "Electronic Surveillance: Commentaries and Statutes". Notre Dame, IN: National Institute for Trial Advocacy, 2003.

Akbar, M. J. "The shade of swords: Jihad and the Conflict between Islam and Christianity". London and New York: Routledge, 2002.

Balkin, Karen. "The war on terrorism: Opposing Viewpoints". Detroid, Ml: Greenhaeven Press, 2005.

Ball, Howard. "The USA PATRIOT ACT of 2001: Balancing Civil Liberties and National Security: A Reference Handbook". Santa Barbara, CA: ABC-CLIO, 2004.

Benjamin, Daniel, and Steven Simon. "The age of sacred terror". New York: Random House, 2002.

Bodansky, Yossef. "Bin Ladin: The man who declared war on America". New York: Random House, 2001. 
Bovard, James. "Terrorism and Tiranny: Trampling Freedom, Justice, and Peace to Rid the World of Evil". New York: Palgrave Macmillan, 2003.

Clarke, Richard A. "Against All Enemies: Inside America's War on Terror". New York: Free Press, 2004.

Collins, Aukai. "My Jihad: The true story of an American Mujahi's amazing journey from Osama Bin Laden's training camps to counterterrorism with the FBI and CIA". Guinfold, CT: Lyons, 2002.

Camargo G., "International Handbook of the Ombusman", Westport, Connecticut, 1983.

Ehrenfeld, Rachel. "Funding Evil: How Terrorism Is Financed-and How to Stop It". Chicago, IL: Bonus Books, 2003.

El-Ayouty, Yassin, ed. "Perspectives on 9/11". Westport, CT: Praeger, 2004.

Emerson, Steven. "American Jihad: The Terrorists Living among Us". New York: Free Press, 2002.

Etzioni, Amitai. "How Patriot is the Patriot Act?: Freedom versus security in the Age of Terrorism". New York: Routledge, 2004.

Ewing, Alphonse B. "The USA PATRIOT ACT". New York: NOvinka Books, 2002.

Farnam, Julie. U. S. "Immigration Laws under the Threat of Terrorism". New York: Algora Pub., 2005.

Ferriera Pinto, "Teoria e pratica do habeas corpus", Ed. Sararia, Rio de Janeiro, 1988.

Gertz, Bill. "Breakdoen: How America's Intelligence Failures Led to September 11". Washington, DC: Regnery Publishing, 2002.

Goldstein, Joshua S. "The real price of war: how you pay for the War on Terror". New York: New York University Press, 2004.

Greenwald, Robert. "Unconstitutional: The War on Our Civil Liberties". New York: Disinformation Co., 2006.

Gunaratna, Rohan. "Inside al Quaeda: Global Network of Terror". New York: Columbia University Press, 2002.

Henderson, Harry. "Terrorist Challenge to America". New York: Facts on File, 2003.

Laqueur, Walter. "No end to war: Terrorism in the Twenty-First Century". New York: Continuum, 2003.

Martin, Gus, ed. "The New Era of Terrorism: Selected Readings". Thousand Oaks, CA: Sage, 2004.

Moore, Michael. "The Official Fahrenheit 9/11 Reader ". New York: Simon \& Schuster Paperbacks, 2006. 